\title{
The Control of The Kadi and The Muhtesib on The Urban Guilds in The Ottoman Empire
}

\author{
Mohammad Hefni \\ (State College for Islamic Studies of Pamekasan, Jl. Panglegur KM. 4, Tlanakan \\ Pamekasan 69371, Email: hefni_mohd@yahoo.com)
}

\begin{abstract}
Abstrak:
Keberhasilan kekaisaran Ottoman sebagai salah satu kerajaan terbesar, terluas, dan terpanjang dalam sejarah dunia tidak dapat dilepaskan dari upaya pemerintah Utsmaniyah untuk mengelola negaranya melalui pembentukan berbagai institusi. Di antaranya adalah lembaga peradilan seperti peradilan kadi dan lembaga $\underline{H}$ isbah yang dipimpin oleh muhtesib. Karenanya, artikel ini membahas hubungan dan interaksi antara kadi dan muhtesib di kekaisaran Utsmaniyah, dan akar sejarahnya pada periode sebelumnya. Jabatan kadi dan muhesib telah ada pada periode sebelum kekaisaran Utsmaniyah. Kadi telah ada sejak masa Nabi Muhammad SAW. Sementara, muhtesib secara historis telah bermula pada jabatan agoranomos di Yunani-Romawi. Di kekaisaran Utsmaniyah, keduanya menjadi fungsi pemerintahan yang penting. Mereka memiliki kekuatan untuk memutuskan segala sesuatu yang berhubungan dengan syari'ah dan hukum yang ditetapkan oleh Sultan. Mereka memainkan peran dalam mengendalikan kehidupan urban, terutama kegiatan ekonominya. Semua kegiatan produksi dan manufaktur di kota-kota dilaksanakan di dalam kerangka organisasi serikat berada di bawah kendali kadi dan muhtesib, misalnya serikat kerajinan dan serikat kreditor.
\end{abstract}

\section{Kata Kunci:}

Kadi, Muhtesib, Kekaisaran Utsmaniyah, dan Serikat Urban

\begin{abstract}
:
Success of the Ottoman empire as one of the greatest, most extensive, and longest-lasting empires in the history of the world could not be released from the efforts of the government to organize the state throught establishment various institutions. Among them are judicials instititution such as kadi courts and $\underline{H}$ isbah institutions which was led by a muhtesib. Therefore, this paper discusses the relationship
\end{abstract}

al-1hkam Vol.12 No.2 Desember 2017

DOI 10.19105/al-ihkam.v12i2.1466 
Mohammad Hefni

and the interaction between the kadi and the muhtesib in the Ottoman empire, and their historical roots in the periods before. The position of a kadi and a muhesib has existed in periods before the Ottoman empire. A kadi has existed since the Prophet Muhammad pbuh period. While, a muhtesib historically has began in the Greco-Roman agoranomos. In the Ottoman empire, both became important governmental functions. They had the power to pronounce decisions on everything connected with the sharî'a and the Sultanic law. They played roles in controlling urban life, its economic activities in particular. All the production and manufacturing activities in the cities that were carried out within the framework of the guild organization was under the control of the kadi and the muhtesib. For example a craft guilds and a creditor guilds.

\section{Keywords:}

Kadi, Muhtesib, Ottoman Empire, dan Urban Guild

\section{Introduction}

The Ottoman Empire was one of the greatest, most extensive, and longest-lasting empires in the history of the world. It ruled over a vast territory on three continents, Europe, Asia, and Africa, ${ }^{1}$ more than six centuries (623 years). The Ottoman Empire contained 29 provinces and numerous vassal state. Some of which were later absorbed into the empire, while others were granted various types of autonomy during the course of centuries. ${ }^{2}$ During the period between $17^{\text {th }}$ and $18^{\text {th }}$ centuries, the population of the empire was over 30 million. ${ }^{3}$

Success of the Ottoman empire could not be released from the efforts of the Ottoman government to organize the state throught establishment various institutions. Among them are judicials instititution. In the Ottoman empire, there were various judicial

\footnotetext{
${ }^{1}$ Irene Bierman, et.al., Islam and the Arts of the Ottoman Empire (n.p: Asian Art Museum Education Department, n.d), 15.

2 Turkish Navy Official, Atlantik'te Türk Denizciliği, available at (http:/ / www. dzkk. tsk. mil. tr/ TURKCE/ TarihiMiras/AtlantikteTurkDenizciligi. Asp, accessed on July 21, 2017.

3 Erkut Duranoglu and Guzide Okutucu, Economic Reasons Behind the Decline of the Ottoman Empire (Master Thesis in International Business, Norges Handelshøyskole [NHH], 2009), 13-4.
} 
institution, i.e kadi (qadlî) courts, hisbah institutions which was led by muhtesib (muhtasib), madhâlim, walâ al-jarầim, and nezir (nadhr).

Various studies of the judicial institutions in the Ottoman empire discuss them separately. Winter compares the profiles of judges (kadis), as well deputy kadis (nâibs), and the personnel of the courts in Damascus within the Mamluk and the Ottoman states. ${ }^{4}$ Peters examines the kadi as one who controls the productios of sharî'ah norms and who has the authority to formulate the rules of the sharî'a. ${ }^{5}$ Canbakal studies vows (nezir, Ar. nadhr) that was began to be used in the central lands of the Ottoman Empire as a means to seal contracts of a public nature. ${ }^{6}$ Kaya studies the role of kadi institution before the political reforms of Abdulmecid in 1839 (Tanzimat), especially in performed the the municipal services. ${ }^{7}$ Sari studies muhtesib as an upholder of the principle of general ethics and as a provider protection for public order (emri bil maruf nehyi anil munker). 8 Şimşek analysis the role oh muhtesib in enforcing the rules for the standardization of food products. ${ }^{9}$ Therefore, this paper discusses the role of the kadi and the muhtesib in controlling te urban guilds in the Ottoman empire, and their historical roots in the periods before.

\footnotetext{
4 Michael Winter, The Judiciary of Late Mamluk and Early Ottoman Damascus: The administrative, Social and Cultural Transformation of the System (Bonn: ASK Working Paper 05, 2012)

5 Rudholph Peters, "From Jurists' Law to Statute Law or What Happens when the Shari'a is Codified", in Shaping the Current Islamic Reformation, 82-93, ed. B.A. Roberson, (London: Ebsco Publishing, 2003).

6 Hülya Canbakal, "Vows as Contract in Ottoman Public Life (17th-18 ${ }^{\text {th }}$ centuries)", Islamic Law and Society, 18 (2011), 85-115.

7 Kemal Kaya, Tanzimat'tan Önce Belediye Hizmetleri ve Voyvodalar (Ankara: Dil ve Tarih-Coğrafya Fakültesi, Ankara Üniversitesi, 2007).

8 Cahide Gulnur Sari, "Hisbe Teskilatı", in Genc Hukukcular Hukuk Okumaları, Birikimler 3, 319-334, ed. Muharrem Balc1 (Istanbul: Hukuk Vakfı, 2009)

9 Ayşe Şimşek, Tarihte Gida Denetimi: Osmanli Bursa Ihtisab Kânunnamesi Örneği, A Paper Presented At International 3nd Halal And Healthy Food Congress, Istanbul, Turkey, October 30-31, 2015, available at www.helalvesaglikli.org/tr/icerikgoster/39, accessed on July 16, 2017.
} 


\section{A Brief History of the Ottoman Empire}

The Ottoman empire had emerged, 1299,10 in western Anatolia (western Asia Minor), ${ }^{11}$ not far from the modern city of Istanbul, along with the demise of the Anatolian Seljuk Sultanate of Rûm.12 By 1300, a weakened Byzantine Empire had lost most of its Anatolian provinces to ten Ghazi principalities. One of the Ghazi emirates was led by Osman I, from which the name Ottoman (in Turkish Osmanli) Beylik (similar to a Principality or Sultabate), is derived, son of Ertuğrul, in the environs of Soğut in Eskişehir in the northwestern corner of the peninsula.

The Ottoman Beylik that ruled over a vast territory on three continents for 623 years, served as a bridge between Eastern and Western cultures. In the $13^{\text {th }}$ century, Ottomans were ruling only one of the Turkmen beyliks that surrounded the Byzantine Empire during its period of decline. In two centuries, Ottomans established an empire including not only Southeastern Europe and Byzantines lands in Anatolia but also, Hungary and Arabian lands. ${ }^{13}$ In the century after the death of Osman I, Ottoman rule began to extend over the Eastern Mediterranean and the Balkans. The important city of Thessaloniki was captured from the Venetians in 1387. The Ottoman victory at the Battle of Kosovo in 138914 effectively marked the end of Serbian power in the region, paving the way for Ottoman expansion into Europe. The Battle of Nicopolis in 1396, widely regarded as the last large-scale crusade of the Middle Ages, failed to stop the advance of the victorious Ottomans. With the extension of Ottoman dominion into the Balkans, the strategic conquest of Constantinople became a crucial objective. The Empire controlled nearly all former Byzantine lands surrounding the city, but the Byzantines were temporarily relieved when Timur invaded Anatolia in the Battle of Ankara in

10 In 1299, Osman I led his armies to conquer Byzantine cities and forts in Turkish Anatolia.

11 Halil Inalc1k and Donald Quataert (eds.), An Economic and Social History of the Ottoman Empire, 1300-1914 (CambridgeL Cambridge University Press, 1994), xviii

12 Huriye Çolaklar, "History of Dentistry from the Period of the Ottoman Empire to the Republican Period", Journal of Pharmacy and Pharmacology, 2 (2014), 680.

13 Stanford S. Shaw, History of the Ottoman Empire and Modern Turkey, Vol. I (Cambridge: Cambridge University Press, 2004), 17.

14 Daniel Goffman, The Ottoman Empire and the Early Modern Europe (Cambridge: Cambridge University Press, 2002), 9. 
1402. He took Sultan Bayezid I as a prisoner. Part of the Ottoman territories in the Balkans (such as Thessaloniki, Macedonia and Kosovo) were temporarily lost after 1402, but were later recovered by Murad II between the 1430s and 1450s.15

The capture of Bayezid I (r.1389-1402)16 threw the Turks into disorder. ${ }^{17}$ The state fell into a civil war that lasted from 1402 to 1413 , as Bayezid's sons fought over succession. It ended when Mehmed I emerged as the sultan and restored Ottoman power, bringing an end to the Interregnum. His grandson, Mehmed the Conqueror, reorganized the state and the military, and demonstrated his martial prowess by capturing Constantinople on May 29, 1453, at the age of 21.

The Ottoman conquest of Constantinople, the capital of the Eastern Roman Empire, 18 in $1453^{19}$ by Sultan Mehmet II (r. 14511481) ${ }^{20}$ cemented the status of the Empire as the preeminent power in southeastern Europe and the eastern Mediterranean. During the reign of Sultan Mehmet II, who assumed the title of "The Conqueror," 21 the Ottoman state entered into an era of rapid development which would last until the end of the sixteenth century. At its height, the Ottomans ruled over what is today Greece, Bulgaria, Yugoslavia, Albania and Romania in the Balkans, over all the islands in the Eastern

15 Gabor Agoston, "Murad II", in Encyclopedia of the Ottoman Empire, eds. Gábor Ágoston \& Bruce Masters, 226-8 (New York: Facts On File, Inc., 2009), 399-401.

16 Shaw, History of the Ottoman Empire, 129.

17Badri Yatim, Sejarah Peradaban Islam (Dirasah Islamiyah II) (Bandung: PT. Raja Grafindo Persada, 2000), 131; Gabor Agoston, 'Bayezid I', in Encyclopedia of the Ottoman Empire, 80-2.

18 Alwi Alatas, al-Fatih Sang Penakluk Konstantinopel (Jakarta: Zikrul Hakm, 2005), 7. In the caseof teh conquest of Constantinople, the Ottomans would recall an Hadîts which said: 'One day Constantinople will definitely be conquered. What a good amir and what a good arnry is the one that will accomplish this". See Evliyā Çelebi, Seyāthatnāme (lstanbul 1314/1895), vol. I as quoted by Halil Inalcik, "Istanbul: An Islamic City", Journal of Islamic Studies, 1 (1990), 1-24.

19 Mehmed II entered Constantinople on May 29, 1453 after a siege lasting less than two months. See Arfan Tulay, The Anatolian Seljuks and The Ottoman Empire, https://research.sabanciuniv.edu/.../Artan,_Tülay_-

_The_Anatolian_Seljuks_and_the_O.., accessed on July 15, 2017.

${ }^{20}$ Edhem Eldem, "Galata (Pera; Sykai)", in Encyclopedia of the Ottoman Empire, 226.

21 See John Freely, The Grand Turk: Sultan Mehed II -Concueror of Constantinople, Master of an Empire and Lord of Two Seas (London: I.B. Tauris, 2009), 33. 
Mediterranean, and over what is today the Middle East. The borders of the Empire extended from the Crimea in the North to Yemen and Sudan in the South and from Iran and the Caspian Sea in the East to Vienna in the Northwest and Spain in the Southwest. After taking Constantinople, Mehmed met with the Orthodox patriarch, Gennadios and worked out an arrangement in which the Orthodox Church, in exchange for being able to maintain its autonomy and land, accepted Ottoman authority. ${ }^{22}$

At the height of its power, in the $15^{\text {th }}$ and $17^{\text {th }}$ centuries, it controlled territory in southeastern Europe, southwestern Asia, and North Africa. ${ }^{23}$ In other words, during these periods, the Ottoman Empire entered a long period of conquest and expansion, extending its borders deep into Europe and North Africa. Conquests on land were driven by the discipline and innovation of the Ottoman military; and on the sea, the Ottoman Navy aided this expansion significantly. The navy also contested and protected key seagoing trade routes, in competition with the Italian city states in the Black Sea, Aegean and Mediterranean seas and the Portuguese in the Red Sea and Indian Ocean. The state also flourished economically thanks to its control of the major overland trade routes between Europe and Asia. ${ }^{24}$

The Empire prospered under the rule of a line of committed and effective Sultans. Sultan Selim I (1512-1520) dramatically expanded the Empire's eastern and southern frontiers by defeating Shah Ismail of Safavid Persia, in the Battle of Chaldiran. ${ }^{25}$ Selim I established Ottoman rule in Egypt, and created a naval presence on the Red Sea. After this Ottoman expansion, a competition started

22 Norman Stone, "Turkey in the Russian Mirror", in Russia War, Peace and Diplomacy, eds. Mark \& Ljubica Erickson, 86-100 (London: Weidenfeld \& Nicolson, 2004), 94.

23Ottoman Empire (Devlet-i Aliyye-i Osmâniyye), 3, available at https://www.alternatehistory.com > ... > Alternate History Discussion: Before 1900, accessed on July 15, 2017.

${ }^{24}$ Kemal H. Karpat, The Ottoman State and Its Place in World History (Leiden: Brill, 1974), 111.

${ }^{25}$ R.M. Savory, "The Principal Offices of the Șafawid State during the Reign of Ismā'il I (907-30/1501-24)", Bulletin of the School of Oriental and African Studies, University of London, Vol. 23, No. 1 (1960), 91-105. 
between the Portuguese Empire and the Ottoman Empire to become the dominant power in the region. ${ }^{26}$

Selim's successor, Suleiman the Magnificent ${ }^{27}$ (1520-1566), ${ }^{28}$ further expanded upon Selim's conquests. After capturing Belgrade in 1521, Suleiman conquered the southern and central parts of the Kingdom of Hungary. After his victory in the Battle of Mohács in 1526, he established Ottoman rule in the territory of present-day Hungary. He then laid siege to Vienna in 1529, but failed to take the city after the onset of winter forced his retreat. ${ }^{29}$

Under Selim and Suleiman, the Empire became a dominant naval force, controlling much of the Mediterranean Sea. ${ }^{30}$ The exploits of the Ottoman admiral Barbarossa Hayreddin Pasha, who commanded the Ottoman Navy during Suleiman's reign, led to a number of military victories over Christian navies. Among these were the conquest of Tunis and Algeria from Spain; the evacuation of Muslims and Jews from Spain to the safety of Ottoman lands (particularly Salonica, Cyprus, and Constantinople) during the Spanish Inquisition; and the capture of Nice from the Holy Roman Empire in 1543.

This last conquest occurred on behalf of France as a joint venture between the forces of the French king Francis I and those of Barbarossa. ${ }^{31}$ France and the Ottoman Empire, united by mutual opposition to Habsburg rule in both Southern and Central Europe, became strong allies during this period. By this time, the Ottoman Empire was a significant and accepted part of the European political sphere. It made a military alliance with France, the Kingdom of

\footnotetext{
${ }^{26}$ Andrew C. Hess, "The Ottoman Conquest of Egypt (1517) and the Beginning of the Sixteenth-Century World War", International Journal of Middle East Studies, Vol. 4, No. 1 (January, 1973), 55-76.

27 The title was given to Sulaiman because of the vastness of Ottoman empire and the development of the empire during his reign. See Hassan Ibrahim Hassan, Sejarah Kebudayaan Islam, trans. Djahdan Human (Yogyakarta: Kota Kembang, 1989), 334.

28 H. Inalcik, Osmanli Imparatorlugu Klasik Cag (1300-1600) (Istanbul: Yapi Kredi Yayinlari, 2006), 9.

29 Colin Imber, The Ottoman Empire, 1300-1650: The Structure of Power (Palgrave Macmillan, 2002), 50.

30 İdris Bostan, "Navy", in Encyclopedia of the Ottoman Empire, 425.

31 Imber, The Ottoman Empire, 53.
} 
England and the Dutch Republic against Habsburg Spain, Italy and Habsburg Austria.

In hindsight, we can see that after 1683 the Ottomans never again threatened central Europe. They did, however, stay in occupation of southeast Europe for 200 more years, dominating the modern-day states of Bulgaria, Serbia, Greece, Rumania, and others. Finally, in the hardly unbiased words of the British politician, Gladstone, they were driven "bag and baggage" from their possessions. In its Asian and African provinces, the Ottoman Empire persisted even longer. Most parts of modern-day Turkey, Syria, Lebanon, Iraq, Israel, Palestine, Jordan, and Saudi Arabia remained part of the empire until World War I.

In 1789, the year of the French Revolution, Selim III (r. 17891807) suceeded to the Ottoman throne. ${ }^{32}$ Raised by Sultan Mustafa III (r. 1757-74), a reformative father, Selim was totally aware of the rapid decline of the Empire when he seized power. So, he was the first Sultan whom recognised the empire's serious decline. After being proclaimed Emperor, he began a programme of reforms along European lines. He started by initiating changes in education, legal and military systems. These reforms were not welcomed by the Janissaries (Ottoman soldiers) who, through the terror of Europe, had now become ineffective on the battlefield. When Selim began developing an infantry force known as the Nizam-i Cedit (New Order) 'it aroused bitter opposition among the Janissaries who saw this new army as a threat to their existence'. ${ }^{33}$

In addition, while the hier apparent, he contacted some European monarchs and eorresponded with Louis XVI of France concerning statecraft, social institutions, and military arts in Europe, ${ }^{34}$ sought inspirations, and attempted to learn means and ways of stopping the Ottoman decline. He was not pessimistic like his predecessors and beleived that "there could be a remedy for

32 Seçil Akgün, "The Emergence of Tanzimat In The Ottoman Empire", OTAM (Ankara Tarihi Arastirma ve Uygulama Merkezi Dergisi), No. 2 (1991), 3.

33 John Freely, Inside the Seraglio: Private Lives of the Sultans in Istanbul (New York: Penguin, 2000), 226.

${ }^{34}$ Kahraman Şakul, "Selim III (b. 1761-d. 1808) (r. 1789-1807) Ottoman Sultan and Caliph, Reformer, and Composer" in Encyclopedia of the Ottoman Empire, eds. Gábor Ágoston \& Bruce Masters, 514-515 (New York: Facts On File, Inc., 2009), 514. 
everything but death". The contacts he made with western ambassadors, again prior to his succession to throne, guided him to regard westernization an unavoidable must to stop the decline.

The Ottoman Empire held reorganization to modernize the state through Tanzimat, which was known as the first reform act. It began in 1839 and ended with the First Constitutional Era in 1876. The Tanzimat Decree was promulgated under the ruler of Abdülmecid I (r. 1839-1861), who was the pioneer of the first democratic attempts of the Ottoman Empire in order to prevent an economic and social disorder in the state. The author of Tanzimat Decree was Mustafa Resid Paşa, a brilliant and remarkable statesman, and a Abdülmecid's Foreign Minister. 35

The reforms was aiming to leave the decision making process to an independent parliament by limiting the absolute power of the sultan. Besides, in the reforms there was new arrangements in education, army, administration, provinces and the society. Besides its economic and social effects, political implications of the prescripts would have deeper effects in economy in the long run. From the Ottoman point of view, the main purpose of declaring Tanzimat was to maintain and preserve the Ottoman state against uprisings and together with, to gain sympathy and diplomatic support of European countries. ${ }^{36}$

To carry out the promises of Tanzimat, the sultan also promulgated Islahat Decree. It was more specific about the religious issues. Since there was a constant pressure on non-Muslims to be converted into Islam, the idea of freedom to practice one's own religion without harassment was promoted by Islahat Decree. ${ }^{37}$

The Tanzimat reforms accelerated the process of secularisation as intended by Sultan Mahmud. The most significant aspect of the innovations initiated by Mahmud II was the emergence of an Ottoman state based on secular aspects of sovereignty as contrasted

\footnotetext{
35 Akgün, The Emergence of Tanzimat, 11.

${ }^{36}$ Duranoglu and Okutucu, Economic Reasons, 33-4.

37 S. Deringil, "There Is No Compulsion in Religion: On Conversion and Apostasy in the Late Ottoman Empire: 1839-1856", Comparative Studies in Society and History, Vol. 42, No. 3 (2000), 547-575.
} 
with the medieval concept of an Islamic empire. The real beginning of modernisation and secularisation was in this change. 38

Despite the mixed success, the Tanzimat reforms were successful in bringing about equality for all citizens, especially nonMuslims who had previously only been tolerated as dzimmis. ${ }^{39}$ They also led to the creation of a new identity known as Ottomanism, 40 which replaced the millet system. Ottomanism (Osmanlilik or Ottoman nationalism), ${ }^{41}$ technically meant that all citizens of the empire were equal in the eyes of the law, regardless of faith, however, in reality old prejudices remained. Therefore, it was a nationalist movement that attempted to foster an ethnically diverse identity for the inhabitants of the Ottoman Empire

Although the Tanzimat reforms never quite produced the results the later Sultans had hoped for, they did improve various aspects of the empire such as the education system and the status of non-Muslims. ${ }^{42}$ It could be argued that, had the empire been around today, it would have had a very similar political structure to modern day Turkey. After all, it was only because of the reforms that the Turkish Republic was able to emerge from the ashes of the Ottoman Empire and resist being colonised by European powers.

During the last decades before it disappeared in November 1, 1922 the Ottoman Empire existed without the European provinces that for centuries had been its heart and soul. ${ }^{43}$ As known, the Ottoman Empire entered the First World War in 1914, allied with the German Empire, on the side of the allied powers and emerged defeated from the war in 1918, compelled to sign the Mondros Armistice on October 30, 1918. Under the terms of this Armistice, the

\footnotetext{
38 M. Hakan Yavuz and John L. Esposito, Turkish Islam and the Secular State (New York: Syracuse University Press, 2003), 244.

${ }^{39}$ Ishtiaq Hussain, The Tanzimat: Secular reforms in the Ottoman Empire (A Brief Look at the Adoption of Secular Laws in the Ottoman Empire with a Particular Focus on the Tanzimat Reforms (1839-1876) (n.p: Faith Matters, 2011), 12.

40 Shaw, History of the Ottoman Empire, 36.

${ }^{41}$ Bram Hubbell, The Ottomans, (New York: Middle East Policy Council, n.d), 2.

42 Hussain, The Tanzimat, 12.

43 Donald Quataert, The Ottoman Empire, 1700-1922 (Cambridge: Cambridge University Press, 2005), 2.
} 
territories of the Ottoman Empire were occupied by Britain, France, Russia, and Greece. ${ }^{4}$ This was the actual end of the Ottoman Empire.

In addition, the occupation of Constantinople along with the occupation of İzmir mobilized the establishment of the Turkish national movement, which won the Turkish War of Independence (1919-22) under the leadership of Mustafa Kemal Pasha. The Turkish War of Independence or National Liberation War was an effort to create a new state from the ruins of an Empire, which had completed its life. It lasted four years (1919-1922) wherein a small army of volunteers fought and won a war against the leading powers of this time. Ataturk's victory was not only military, but it was also diplomatic. The Turkish military victory was sealed with a diplomatic success with the signing of the Lausanne Peace Treaty on July 24, 1923. Signed with Great Britain, France, Greece, Italy and others, the Treaty recognized the creation and international borders of a Turkish State and guaranteed its complete independence.

The Sultanate was abolished on 1 November 1922, and the last sultan, Mehmed VI Vahdettin (r. 1918-1922), left the country on November 17, 1922. The new independent Grand National Assembly of Turkey (GNA) was internationally recognized with the Treaty of Lausanne on 24 July 1923. The GNA officially declared the Republic of Turkey on 29 October 1923.45 The Caliphate was constitutionally abolished several months later, on 3 March 1924. The Sultan and his family were declared personae non gratae of Turkey and exiled.

The Republic of Turkey was proclaimed on October 29, 1923. For the first time in centuries, the Turkish people enjoyed self-rule. Mustafa Kemal Pasha was elected as the first president of the Republic of Turkey. Mustafa Kemal was given the last name -Atatürk (meaning -Father of the Turks), a privilege reserved for him alone. ${ }^{46}$

\footnotetext{
44 Turkish Cultural Foundation (TCF), A Brief Outline of Turkish History, 98, available at www.turkishculture.org/general-1067.htm, accessed on July 11, 2017.

45 Stanford J. Shaw and Ezel Kural Shaw, History of the Ottoman Empire and Modern Turkey, Vol. II, Reform, Revolution, and Republic, The Rise of Modern Turkey 1808-1975 (Cambridge: Cambridge University Press, 2004), 21.

46 Isputaminingsih, Negara Turki Modern ala Musthafa Kemal Pasha (Bandung: Iris Press, 2009), 12 and Diana Aschner, et.al., History \& Culture of Turkey: From Anatolian Civilization to Modern Republic (Ankara: Global Focus Chatham University, 2009), 5.
} 


\section{The Role of the Kadi and the Muhtesib in Controlling the Urban} Guilds in the Ottoman Empire and Their Historical Roots

In the Ottoman Empire, the Ottoman legal system, as it emerged during the sixteenth century, was based on two pillars, namely the Ottoman law and the Ottoman judicial institutions. ${ }^{47}$ The Ottoman law was the result of the interaction between the Ottoman, Hanafite, ${ }^{48}$ jurists, and state officials. This interaction produced its effects in two fields: the transformation of Hanafite legal discourse into a body of unambiguous and consistent legal rules and the creation of enacted laws (qânûn), supplementing the shari'a.

As for the Ottoman judicial institutions, they were characterised by jurisdictions that were clearly defined by enacted laws. Their powers were distributed in such a way that the actors, i.e. the kadis (who were the guardians of the classical jurisprudence) ${ }^{49}$ and the executive officials, kept one another in check.

The kadi courts that was led by a kadi exercised at least three functions, namely: (1) the registration of acts of private law (transfers and registrations of land and property, deeds of credit and debt, identity declarations, quittances), as performed by public notaries; (2) the issue of decrees or sentences, always on the basis of written evidence, in civil law litigation (marriage and dowry cases, divorce and maintenance allowances, property and goods litigation, claims by peasants, and landlords, regulation of prices according to the information by the officials, charged to keep order in the markets); and also criminal cases, from small fights and curses up to the attribution of blood money (dem and diyet) in cases of violent death;

47 Rudolph Peters, Crime and Punishment in Islamic Law: Theory and Practice from the Sixteenth to the Twenty-first Century (New York: Cambridge University Press, 2005), 70.

48 Under the Ottomans, the Hanafi school (school of jurisprudence founded by the jurist Abû Haniffa 699-767) was the preferred or 'official' school of law. See Lynn Welchman, Women and Muslim Family Laws in Arab States: A Comparative Overview of Textual Development and Advocacy (Amsterdam: Amsterdam University Press, 2007), 12.

49 Sadiq Reza, "Due Process in Islamic Criminal Law”, Geo. Wash. Int'l L., Vol. 46, Rev. 1 (2013-2014), 6. 
and (3) also the mediation, or registration, of voluntary accords or "reconciliations" (sulh $) .50$

In addition to these strictly judicial functions, kadis could be called upon to appoint overseers of pious foundations (Vafk or Evkaf), ${ }^{51}$ guardians for orphans and minors; to generally supervise tax collection and to see that population and fiscal records were kept accurately and safely. They also investigated cases brought before them by local police officers, especially responsible for order at night, taverns, drinking, and moral misconduct. ${ }^{52}$

So, the kadis occupied a key role: he monitored the lawfulness of the acts of other officials involved in criminal justice and thus ensured the legal basis of criminal proceedings, including interrogation and custody of suspects. For his part, the kadi's conduct was checked by the local governor and the Sultan, who could open detailed investigations of a kadi's dealings and, if necessary, dismiss and imprison him. An overall corrective to ensure the fair working of the system was the right of the people to submit petitions to the central government. As a rule these were taken seriously and could result in the sending of a commission of inquiry to examine alleged abuses.

Under the system in the late Ottoman Empire, religious offcials, notably the kadis had been appointed by the Ottoman central government. ${ }^{53}$ However, the kadi was bound by Islamic law and his own conscience in regard to that law, ${ }^{54}$ the sharia, sultanic law (qanûn),

\footnotetext{
50 Elena Brambilla, "Convivencia under Muslim Rule: the Island of Cyprus after the Ottoman Conquest (1571-1640)", in EU-Turkey Dialogue, A Cliohworld Reader, http://www.cliohwrld.net/., 130.

51 The Pious Foundation also known as Evkaf Foundation (Vakiflar Idaresi) or wakf, oversees Islamic charitable land holdings. See Kenan İnan, "The Making of Kanun Law in the Ottoman Empire, 1300-1600", in Creating a New Historical Perspective: EU and the Wider World (Cliohworld Readers I, eds. Gudmundur Halfdanarson and Hatice Sofu, 99-110 (Pisa: Edizioni Plus - Pisa University Press, 2011), 105.

52 Brambilla, "Convivencia under Muslim Rule", 130.

${ }^{53}$ Rashid Khalidi, The Iron Cage: The Story of the Palestinian Struggle for Statehood (Great Britain: Oneworld Publications, 2007), 53.

54 Marai Boauod, The Making of Modern Egypt: The Egyptian Ulama as Custodians of Change and Guardians of Muslim Culture (MA. Thesis in History, Portland State University, 2016), 48.
} 
and customary law. ${ }^{55}$ Kadis, as government appointees, were financially remunerated by the ruler for their work. 56

The position of a kadi himself has existed in Prophet Muhammad pbuh (d. 632 ce) period. It was reported that the Prophet

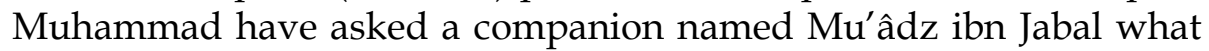
he would use as a source of law upon his deployment as a kadi (judge and administrator) to Yemen (kayfa taqdlî idzâ 'uridla laka qadhâ'). Ibn Jabal was believed to have answered "Aqdlî bi kitâb Allâh (I will judge with what is in the book of God). He was then asked by the Prophet 'If you do not find a clue in the book of God?' Ibn Jabal answered, 'Fa bi sunnati Rasûlillâh (then with the Sunnah of the Messenger of God?)' The Prophet then asked, 'If you do not find a clue there in?' Ibn Jabal

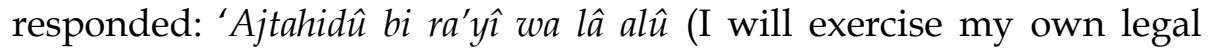
reasoning'. The Prophet was believed to be perfectly satisfied with this response. ${ }^{57}$ Here, the Prophet have asked $\mathrm{Mu}^{\prime}$ âdz by using the word "taqdhî", and Mu' âdz have answered by using the word "aqdh $\hat{\imath}$ ".

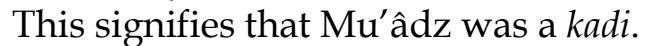

On the Khulafâ al-Râsyidîn period, similar with the legal systems of ancient Rome and Greek and also Europe in the Middle Ages, Islamic law did not provide for a proper separation between judicial and executive powers. In other words, the Islamic law was based on the theory of a universal state. ${ }^{58}$ It assumed that mankind were boud and governed ultimately by one ruler. It was the Caliph himself who administered justice. During the reign of the first four rightly-guided caliphs, Abû Bakr al-Shiddîq chaliph, the authority of ijtihâd was exercised primarily by the caliph, even though juristic consultation was common. This era had no concept of separation of power. The power to govern and the power to decide disputes belonged to the caliph. The kadis do appear, however, when the

55 Antonis Anastasopoulos, "Non-Muslims and Ottoman Justice/S?1", in Law and Empire: Ideas, Practices, Actors, eds. Jeroen Duindam, et.al, 275-292 (Leiden and Boston: Brill, 2013), 277.

${ }^{56}$ Hallaq, An Introduction, 13.

57 See Sunan Abû Dawûd, Book 14 Kitâb al-Jihâd, Number 3585, available at www.usc.edu/dept/MSA/fundamentals/hadithSunnahh/abudawud, accessed on May 22, 2017.

58 Majid Khadduri, "Islam and the Modern Law of Nations", The American Journal of International Law, Vol. 50 (1956), 358. 
empire expands. ${ }^{59}$ Still the caliph serves as the ultimate court. Furthermore, the secular was not separated from the sacred, as the caliph exercised the authority both as a worldly leader and as an imâm (the religious leader). Caliphate and imamate resided in one and the same person. This merger made sense because the first four caliphs simply followed the model of power that the prophet himself had exercised. Those who adhere to the classical period of the first four caliphs still argue that Islamic state does not allow any separation of powers.

It was only under the rule of the Caliph 'Umar ibn alKhaththâb that judges were appointed. However, these judges, referred to as kadis in Islamic law, were regarded as the delegates of the Caliph or of the governor of a province. A kadi court was usually a single-judge court with general jurisdiction - there were no specialist courts dealing for instance with just criminal or just civil cases.

The kadi court fulfilled a number of functions. The most important were: (1) the resolution of disputes between two parties either through a compromise between the litigants or through a coercive judgement; (2) the enforcement of claims made by plaintiffs once they have been proven; (3) the protection of the property rights of mentally ill people for instance by appointing a guardian charged with looking after their interests; (4) the administration of pious foundations (waqfs) if no administrator had been appointed; (5) the execution of testamentary provisions of the testator as long as they are lawful; and (6) the application of hadd punishments and the exercise of police powers within the area under his jurisdiction. ${ }^{60}$ The exercise of the function of a kadi was regarded as a religious duty.

The most important was to consider all people equally and to act impartially. The kadi was supposed to listen carefully to the evidence given by the witnesses, to encourage compromise between parties as long as the agreement did not violate principles of Islam or was otherwise illegal, and to give judgement. Kadis were not bound

59 Ali Khan, "The Reopening of the Islamic Code: The Second Era of Ijtihad", University of St. Thomas Law Journal, Vol. 1, (2003), 19.

60 Martin Lau, "The Independence of Judges Under Islamic Law, International Law and the New Afghan Constitution", ZaöRV, No. 64 (2004), 920-1. 
by previous judgements and no rule of binding precedent emerged in Islamic law.

On the period of the Umayyad dynasty (r. 41-132/661-750 $\mathrm{CE})$, governors exercised plenary judicial authority and usuaily delegated dispute settlement to their legal secretary (kadi) whose decisions were subject to gubernatorial review. As it was known, the Umayyad dynasty transferred the seat of Muslim power from Medina to Damascus. As a result, the Islamic empire extended from Spain across North Africa and the Middle East to the borders of China. ${ }^{61}$ Faced with administering a vast bureaucratic organization, the Caliphs delegated territorial power to subordinates who exercised administrative control-governors, military commanders, treasury officials, and water and market inspectors. Therefore, the governors appointed their kadi. The kadi was also in charge of the granary and usually served as the chief of police and master of the treasury. It was not until the kadi end of the Umayyad period that the kadi became exclusively concerned with judicial affairs. ${ }^{62}$

By the turn of the century (715-720), kadis increasingly began to be drawn from the community of pious Muslims. A group of religious scholars who objected to the pragmatism of the Umayyad courts undertook the task of conforming legal rules to the Qur'an. The task of translating these Qur'anic injunctions into practice, however, was complicated by the fact that they developed not in close connexion with the practice, but as the expression of a religious ideal in opposition to it. 63

By the time of the Abbasid dynasty, kadis were full-time judicial officials and were free from gubernatorial and political control. The chief kadi was appointed, but he appointed and supervised the other kadis. In practice, however, kadis were subject to dismissal at the discretion of the central government, which also

\footnotetext{
61 John Esposito, Islam and Politics (New York: Syracuse University Press, 1991), 12. 62 J. Schacht, An Introduction of Islamic Law, (Oxford: Oxford University Press, 1959), 29.

${ }^{63}$ Noel J. Noulson, A History of Islamic Law (Edinburgh: Edinburgh University Press, 1978), 27 and Matthew Lippman, "Islamic Criminal Law and Procedure: Religious Fundamentalism v. Modern Law", Boston College International and Comparative Law Review, Vol. 12, Iss. 1 (1989), 31.
} 
The Control of The Kadi

controlled the jurisdiction of the sharî'a courts and which was responsible for executing the courts' judgments. ${ }^{64}$

In areas concerning primarily civil matters, power was delegated to several individuals. Among them was the Inspector of the Marketplace (muhtesib) who was called kol oğlanlari. ${ }^{65}$ Muhtesib was an appointed officer in charge with ihtisâb. ${ }^{66}$ It derived from the word hisbah. ${ }^{67}$ The word hisbah itself is not Qur'anic, however the principle of hisbah is found in the Qur'an in a common formulation; 'amr bi al$m a^{\prime}$ rûf wa al-nahy 'an al-munkar (the injunction of what is known good and prohibition of what is known evil). ${ }^{68}$ All ethical-social action with the purpose of establishing good and preventing evil in the society was based by the Muslim jurists on this Qur'anic principle.

The muhtesib's duty transcended that of a simple market inspector (shâhib al-sûq) or supervisor of bazaars ${ }^{69}$ such as the GrecoRoman agoranomos. ${ }^{70}$ Historically, the ancient market supervisory

${ }^{64}$ Lippman, "Islamic Criminal Law, 33.

${ }^{65}$ Eunjeong Yi, Guild Dynamics in Seventeenth-Century Istanbul: Fluidity and Leverage (Leiden: E.J. Brill, 2004), 182.

66 Mustafa İsmail Kaya, Shops and Shopkeepers in the Istanbul İhtisâb Register of 1092/1681 (Master Thesis in the Department of History, Bilkent University, Ankara, 2006), 54. The verb ihtasaba, which is another related word from the same root family, on the other hand, means "to take into consideration," "to act with calculation," "to anticipate a reward of something in the hereafter by adding a pious deed to one's account with God." therefore, muhtesib means the person who 'asks for good deeds' and 'forbids bad deeds'. See V. Aytar, Entertainment \& Leisure Consumption in Istanbul (Istanbul: New Market Press, 2014), 63.

${ }^{67}$ Hisbah is an Arabic word which has a variegation of definitions in sources including the reward of something, calculation, and price and measure supervisions. The root of the word, hasaba, means "to count, to compute," "to measure," "to suppose." See Atabik Ali and Ahmad Zuhdi Muhdlor, Qâmîs Karabiyâk al-'Ashrî: 'Arabî-Indonesî (Yogyakarta: Multi Karya Grafika, 1998), 764-5 and A.W. Munawwir, Kamus alMunawwir Arab Indonesia (Surabaya: Pustaka Progressif, 1984), 261.

68 The Qur'an 3: 104, 110, and 114.

69 Sofia Mazgarova, "Islamic Reformism on the Periphery of the Muslim World: Rezaeddin Fakhreddin (1895-1936)", CGU Theses \& Dissertations, Paper 8 (2010), 97.

${ }^{70}$ Benyamin R. Foster, "Agoranomos and Muhtesib", Journal of the Economic and Social History of the Orient, Vol. 13, No. 2 (April, 1970), 128-14, in particular 141. Agoranomos (Greek: áyopavónos, plural: agoranomoi, áyopavó $\mu o t)$ was an electable official position in the cities of Ancient Greece and Byzantine Empire that controlled the order of the marketplace (agora, hence the name, translated as "market overseer"). Wikipedia, the Free Encyclopedia, "Agoranomos", available at https://en.wikipedia.org/wiki/Agoranomos, accessed on July 12, 2017. 
institutions, such as those developing in the Greco-Roman agoranomos, continued to be an important governmental function in Ummayad period. In this period, shâhib al-sîq had the duty of controlling the market. In addition, he argued people to abide regulations on his own initiative. ${ }^{71}$

At the end of the 9th century, during the reign of the Abbasid caliphate, the office of the market inspector began to be regarded as a religious office and the inspector was known as muhtesib, a person who was in charge of investigating the actions of the right and wrong members of society, then reporting them in a note to a book..$^{72}$

When, this market inspector transformed into a muhtesib, with his office portrayed as part of a religious institution, especially related to the function of the Qur'anic teaching, "injunction of what is known good and prohibition of what is known evil " (al-amr bi al-ma'rûf wa nahy' 'an al-munkar). Its main function remained as a market inspector, but muhtesib was formed as a transformation step with a religious role, which of course embodied the religious goal itself. ${ }^{73}$

Whatever its institutional origin, it is in fact an Islamic religious office. Under the Ottomans, the muhtesib was nominated by the kadi and appointed by the Sultan's diploma, which defined his authority and responsibilities. In principle, he was responsible for seeing to it that Muslims in the city followed the precepts of the sharî'a and lived a thoroughly Muslim life. In cooperation with the $k a d i$, he was responsible for affairs bearing on public morality as the sharîa defines it. The muhtesib worked in hisbah organization ${ }^{74}$ with a religious office.

Because of it, its incumbent had to be a religious man with knowledge of Islamic jurisprudence. The Ottoman Sultans appointed a muhtesib in each major city and promulgated hisbah regulations.

71 Ilber Ortayli, "On the Role of the Ottoan Kadi in Provincial Administration", Turkish Public Administration Annual 3 (1076), 12.

72 Aan Jaelani, Markets and Hisbah Institutions: A Theory of Market in the History of Islamic Economic Thought (MPRA Paper No. 71921, posted 25 June 2016), available at https://mpra.ub.uni-muenchen.de/71921/, accessed on October 12, 2017, 34.

73 S.D. Goitein, Studies in Islamic History and Institutions (Leiden: University of Leiden, 1968), 217-241.

74 Orhan Oguz and Ahmed Tabakoglu, "An Historical Approach to Islamic Pricing Policy: A Research on the Ottoman Price System and its Application", JKAU: Islamic Econ., Vol. 3 (1411 A.H./1991 A.D.), 64. 
However, the muhtesib under Ottoman rule, as in earlier times, under the 'Abbasids for example, was active only in the commercial zone and not in the residential zone. His main concerns were to prevent fraud in the marketplace, to apply the hisbah (ihtisab) regulations, and to uphold the declared price lists. One of his most important duties was to check the accuracy of weights and measures at the market. ${ }^{75}$ This restriction of his jurisdiction to the marketplace can be explained by the fact that inviolability of an individual's privacy was the most important rule, and moral supervision was left to the mahalle community and its leader, the imâm.

Together with the kadi, who had the power to pronounce decisions on everything connected with the sharî'a and the Sultanic law, the muhtesib without doubt performed a major role in controlling urban life, its economic activities in particular. ${ }^{76}$ Therefore, the kadi and the muhtesib lived in the city, who were the notables ${ }^{77}$ in the urban population. ${ }^{78}$ The muhtesib controlled and supervised many aspects of trade and urban economy. He performed them in the legal framework, the ihtisâb kanunnameleri (ihtisâb codifications and regulations). These codifications were assigned by the $k a d \imath$ and the muhtesib to organize and regulate the market. ${ }^{79}$

The economic activities of urban life included all the production and manufacturing activities in the cities that were carried out within the framework of the guild ${ }^{80}$ (esnaf) ${ }^{81}$ organization, as one

\footnotetext{
75 Ibid.

76 Inalcik, "Istanbul: An Islamic City", 16-7.

77 Among the urban population, there existed a group enjoying a low profile, such as water-carriers, salesmen, porters, servants, peddlers, caratekers, and dayly workers.

78 Fatma Acun, "A Portrait of the Ottoman Cities", The Muslim Worid, Vol. 92 (Fall, 2002), 271.

${ }^{79}$ Kaya, Shops and Shopkeepers, 51.5

80 Şevket Pamuk, "Institutional Change and the Longevity of the Ottoman Empire, 1500-1800", Journal of Interdisciplinary History, Vol. XXXV, No. 2 (Autumn, 2004), 231. Arabic and Turkish writers have used the terms hirfah, thấ'ifah, sinf, etc. for guild, but these terms are not very precise. They mean many other things in addition to 'profession and professional organization'. Therefore, some writers on economic history of Middle East prefer the use of "guild" itself which signifies that 'all the people occupied in a branch of the urban economy within a definite area constitute a unit which fulfils at once and the same time various functions, such as economically restrictive practices, fiscal, administrative or social functions' with a condition that a framework of officers exists which is headed by a chosen member of that unit. See
} 
of religious and professional organizations.82 It set well-defined rules and regulations since $12^{\text {th }}$ century. ${ }^{83}$ The guild organization fulfilled economic, administrative, social, and fiscal funtions. ${ }^{84}$ Here, the government's control of a guild was carried on through various agents such as the kadi, the muhtesib and various agents of the Sultan. ${ }^{85}$ The economic aspects of the guilds, the quality of the products and the good behavior of the members were the responsibility of the lonca ${ }^{86}$ officials, whereas, the state officials (muhtesib and his men) supervised the quality of the goods, suggested narh system, 87 and controlled accuracy of weights and measures used in markets in order to prevent fraud. 88

Gabriel Baer, "Guilds in Middle Eastern History", in Studies in the Economic History of the Middle East, 11-30, ed. M.A. Cook (London: Psychology Press, 1970), 12.

81 Kenan İnan, "Remembering the Good Old Days: the Ottoman Nasihatname (Advice Letters) Literature of the 17th Century", in Institutional Change and Stability Conflicts, Transitions, and Social Values, eds. Andreas Gémes, Florencia Peyrou, and Ioannes Xydopoulos, 111-127 (Pisa: Pisa University Press, 2009), 118.

82 Gabor Agoston, "Administation, Central", in Encyclopedia of the Ottoman Empire, 1113,12 .

83 A. Verhulst, The Rise of Cities in North-West Europe (Cambridge: Cambridge University Press, 1999), 142, as quoted by Wantje Fritschy, "State Formation and Urbanization Trajectories: State Finance in the Ottoman Empire before 1800, as Seen from A Dutch Perspective", Journal of Global History, 4 (2009), 418.

84 Gabriel Baer, "The Administrative, Economic, and Social Funtions of Turkish Guilds", International Journal of Middle East Studies, Vol. 1 (1970), 28-50.

85 Abdul Azim Islahi, Muslim Economic Thinking and Institutions in the $10^{\text {th }} \mathrm{AH} / 16^{\text {th }} \mathrm{CE}$ Century (Jeddah: Scientific Publising Centre, King Abdulaziz University, 2009), 49.

86 It is argued that the use of the term lonca appeared sometime during the seventeenth century. The word originally had a physical allusion; it was generally used to refer to the common areas of the guilds. Later, lonca came to refer to an organized guild with a physical base. Relationship between Muslim and non-Muslim merchants enabled common usages of some terms. Loca, later lonca, could have been one of these, possibly a borrowing from the Italian merchants. The origin of the word is Italian loggia. See Ahmet Kal'a, "Lonca," in Istanbul Ahkam Defterleri: Istanbul Esnaf Tarihi. Vols 1, eds. Ahmed Kal'a, et. al. (Istanbul: Istanbul Büyükşehir Belediyesi, 1997), 112.

87 Narh is a term used in the Ottoman empire for the prices determined by government authorities for various goods. See Miki Iida-Sohma, "The Textile Market in Istanbul and Bursa in the First Half of the Seventeenth Century: An Introduction", Mediterranean world = 地中海論集, 19 (2008), 163.

88 Kaya, Shops and Shopkeepers, 51. 
For example, a craft guilds in certain urban centers of the Ottoman Empire. Initially, they were under the control of the muhtesib and the $\mathrm{kad} \imath$ in determining the fixed market price, maintaining the quality of goods, and opening shops wherever they wished with first receiving a master's certificate. Before the $18^{\text {th }}$ century, through coordinated action between the guild elders, the kadi, and the muhtesib formulated and adopted rule books (nizamname) to regulate the structure and operation of their guilds. ${ }^{89}$ When first adopted, these books enabled the members of the guild to collectively define and sanctify the boundaries of their activities under the patronage of the state. Next, the entrance of kapıkulu (the salaried permanent troops) ${ }^{90}$ into the town-guilds freed them from the control of the muhtesib and $k a d l$, enabling them to alter the guild structure to their own advantage..$^{91}$

As well, the kadis were responsible to settle small scale usury, and the muhtesib would control the market (bazaar) to eliminate any possibility of usury. ${ }^{92}$ As it is known, in the Ottoman Empire had a guild of creditors, namely sarrafs. In 1750, the guild of creditors had a membership of 72 and 89 in $1835 .{ }^{93}$ Having their own guild and establishing special and private partnerships with the Ottoman elites, sarrafs played a significant role in fiscal matters with growing importance throughout the life span of the Ottoman Empire. The sarrafs were active in the financing of trade and in the guilds. ${ }^{94}$ In general, they were free to lend with interest. Here, the kadi together with the muhtesib were reponsible to control any possibility which was disadvantageous for the creditors.

89 Onur Yildirim, "Ottoman Guilds as a Setting for Ethno-Religious Conflict: The Case of the Silk-thread Spinners' Guild in Istanbul", IRSH, 47 (2002), 411.

90 Veysel Şimşek, Ottoman Military Recruitment and the Recruit: 1826-1853 (Master's Thesis at the Department of History, Bilkent University, Ankara, 2005), 11.

91 Onur Yildirım, "Craft Guilds in the Ottoman Empire (c. 1650-1826): A Survey “, METU Studies in Development, Vol. 27, No. 3-4 (2000), 109.

92 Mehmet Akif Berber, From Interest To Usury: The Transformation Of Murabaha In The Late Ottoman Empire (MA. Thesis, the Graduate School of Social Sciences of İstanbul Şehir University, 2014), 51.

93 A. Scahiner, The Sarrafs of Istanbul: Financiers of the Empire (MA dissertation, Department of History, Bogh Aziçi University, 1995), 78-83.

94 Şevket Pamuk, "The Evolution of Financial Institutions in the Ottoman Empire, 1600-1914", Financial History Review, Vol. 11, No. 1 (2004), 21. 


\section{Conclusion}

The kadi and the muhtesib have exixted since pre-Ottoman empire period. The kadi has exixted in Muhammad pbuh period, while the muhtesib has existed since ancient Greek period. They, with the serious management of the Ottoman government, in he next development became the institutios that has been able to sustain the country's sustainability for a very long time. They were responsible to control the bazaar, especially the urban gulds, so the market prices were fixed and the quality of goods produced were maintained.

\section{Bibliography:}

Acun, Fatma. "A Portrait of the Ottoman Cities", The Muslim Worid, Vol. 92 (Fall, 2002).

Agoston, Gabor. "Administation, Central", in Encyclopedia of the Ottoman Empire, eds. Gábor Ágoston \& Bruce Masters, New York: Facts on File, Inc., 2009.

-----. "Murad II", in Encyclopedia of the Ottoman Empire, eds. Gábor Ágoston \& Bruce Masters, New York: Facts on File, Inc., 2009.

Akgün, Seçil. "The Emergence of Tanzimat In The Ottoman Empire”, OTAM (Ankara Tarihi Arastirma ve Uygulama Merkezi Dergisi), No. 2 (1991).

Akgündüz, Ahmed. İslam Hukukunda Kölelik-Câriyelik Müessesesi ve Osmanlı'da Harem. İstanbul: OSAV, 1995.

Alatas, Alwi. al-Fatih Sang Penakluk Konstantinopel. Jakarta: Zikrul Hakm, 2005.

Ali, Atabik and Ahmad Zuhdi Muhdlor, Qâmûs Karabiyâk al-'Ashrî: 'Arabî-Indonesî. Yogyakarta: Multi Karya Grafika, 1998

Anastasopoulos, Antonis. "Non-Muslims and Ottoman Justice/S?1", in Law and Empire: Ideas, Practices, Actors, eds. Jeroen Duindam, et.al, Leiden and Boston: Brill, 2013.

Aschner, Diana, et.al., History $\mathcal{E}$ Culture of Turkey: From Anatolian Civilization to Modern Republic. Ankara: Global Focus Chatham University, 2009. 
Aytar, V. Entertainment $\mathcal{E}$ Leisure Consumption in Istanbul (Istanbul: New Market Press, 2014.

Baer, Gabriel. "Guilds in Middle Eastern History", in Studies in the Economic History of the Middle East, ed. M.A. Cook. London: Psychology Press, 1970.

--.-. "The Administrative, Economic, and Social Funtions of Turkish Guilds", International Journal of Middle East Studies, Vol. 1 (1970)

Berber, Mehmet Akif. From Interest to Usury: The Transformation Of Murabaha In The Late Ottoman Empire. MA. Thesis, the Graduate School of Social Sciences of İstanbul Şehir University, 2014.

Bierman, Irene. et.al., Islam and the Arts of the Ottoman Empire. n.p: Asian Art Museum Education Department, n.d.

Boauod, Marai. The Making of Modern Egypt: The Egyptian Ulama as Custodians of Change and Guardians of Muslim Culture. MA. Thesis in History, Portland State University, 2016.

Bostan, İdris. "Navy", in Encyclopedia of the Ottoman Empire, eds. Gábor Ágoston \& Bruce Masters, 422-6. New York: Facts On File, Inc., 2009.

Brambilla, Elena. "Convivencia under Muslim Rule: the Island of Cyprus after the Ottoman Conquest (1571-1640)", in EU-Turkey Dialogue, A Cliohworld Reader, http:/ / www.cliohwrld.net/.,.

Canbakal, Hülya. "Vows as Contract in Ottoman Public Life $\left(17^{\text {th }}-18^{\text {th }}\right.$ centuries)", Islamic Law and Society, 18 (2011).

Çelebi, Evliyā. Seyāthatnāme, vol. I. 1stanbul 1314/1895.

Çolak, Bahar. Portraits of Women in the Late Nineteenth Century Ottoman Empire from the Pen of Ahmed Midhat Efendi. Master Thesis in the Department of History, Bilkent University, Ankara, 2002.

Çolaklar, Huriye. "History of Dentistry from the Period of the Ottoman Empire to the Republican Period", Journal of Pharmacy and Pharmacology, 2 (2014).

Deringil, S. "There Is No Compulsion in Religion: On Conversion and Apostasy in the Late Ottoman Empire: 1839-1856", Comparative Studies in Society and History, Vol. 42, No. 3 (2000)

Duranoglu, Erkut and Guzide Okutucu. Economic Reasons Behind the Decline of the Ottoman Empire. Master Thesis in International Business, Norges Handelshøyskole (NHH), 2009. 
Eldem, Edhem. "Galata (Pera; Sykai)", in Encyclopedia of the Ottoman Empire, eds. Gábor Ágoston \& Bruce Masters, New York: Facts on File, Inc., 2009.

Erdem, Hakan. Slavery in the Ottoman Empire and Its Demise, 1800-1909. Oxford: St Antony's College, 1996.

Esposito, John. Islam and Politics. New York: Syracuse University Press, 1991.

Foster, Benyamin R. "Agoranomos and Muhtesib", Journal of the Economic and Social History of the Orient, Vol. 13, No. 2 (April, 1970)

Freely, John. Inside the Seraglio: Private Lives of the Sultans in Istanbul. New York: Penguin, 2000.

--------. The Grand Turk: Sultan Mehed II -Concueror of Constantinople, Master of an Empire and Lord of Two Seas. London: I.B. Tauris, 2009.

Fritschy, Wantje. "State Formation and Urbanization Trajectories: State Finance in the Ottoman Empire before 1800, as Seen from A Dutch Perspective", Journal of Global History, 4 (2009).

Goffman, Daniel. The Ottoman Empire and the Early Modern Europe. Cambridge: Cambridge University Press, 2002.

Goitein, S.D. Studies in Islamic History and Institutions. Leiden: University of Leiden, 1968.

Hassan, Hassan Ibrahim. Sejarah Kebudayaan Islam, trans. Djahdan Human. Yogyakarta: Kota Kembang, 1989.

Hess, Andrew C. "The Ottoman Conquest of Egypt (1517) and the Beginning of the Sixteenth-Century World War", International Journal of Middle East Studies, Vol. 4, No. 1 (January, 1973).

Hubbell, Bram. The Ottomans. New York: Middle East Policy Council, n.d.

Hussain, Ishtiaq. The Tanzimat: Secular reforms in the Ottoman Empire (A Brief Look at the Adoption of Secular Laws in the Ottoman Empire with a Particular Focus on the Tanzimat Reforms (1839-1876). n.p: Faith Matters, 2011.

Iida-Sohma, Miki. "The Textile Market in Istanbul and Bursa in the First Half of the Seventeenth Century: An Introduction", Mediterranean world = 地中海論集, 19 (2008), 161-97.

Imber, Colin. The Ottoman Empire, 1300-1650: The Structure of Power. Palgrave Macmillan, 2002. 
Inalcık, Halil and Donald Quataert (eds.). An Economic and Social History of the Ottoman Empire, 1300-1914. Cambridge University Press, 1994.

--------.-.- "Istanbul: An Islamic City", Journal of Islamic Studies 1 (1990).

---_.--. Osmanli Imparatorlugu Klasik Cag (1300-1600). Istanbul: Yapi Kredi Yayinlari, 2006.

İnan, Kenan. "The Making of Kanun Law in the Ottoman Empire, 1300-1600", in Creating a New Historical Perspective: EU and the Wider World (Cliohworld Readers I, eds. Gudmundur Halfdanarson and Hatice Sofu, 99-110. Pisa: Edizioni Plus - Pisa University Press, 2011.

--_------. "Remembering the Good Old Days: the Ottoman Nasihatname (Advice Letters) Literature of the 17th Century", in Institutional Change and Stability Conflicts, Transitions, and Social Values, eds. Andreas Gémes, Florencia Peyrou, and Ioannes Xydopoulos, 111-127. Pisa: Pisa University Press, 2009.

Islahi, Abdul Azim. Muslim Economic Thinking and Institutions in the 10 $0^{\text {th }} \mathrm{AH} / 16^{\text {th }} \mathrm{CE}$ Century. Jeddah: Scientific Publising Centre, King Abdulaziz University, 2009.

Isputaminingsih. Negara Turki Modern ala Musthafa Kemal Pasha. Bandung: Iris Press, 2009.

Jaelani, Aan. Markets and Hisbah Institutions: A Theory of Market in the History of Islamic Economic Thought (MPRA Paper No. 71921, posted 25 June 2016), available at https://mpra.ub.unimuenchen.de/71921/, accessed on October 12, 2017.

Jennings R.C, Christians and Muslims in Ottoman Cyprus and the Mediterranean World, 1571-1640. New York-London: New York University Studies in Near Eeastern Civilization, XVIII, 1993.

Kal'a, Ahmet. "Lonca," in Istanbul Ahkam Defterleri: Istanbul Esnaf Tarihi. Vols 1, eds. Ahmed Kal'a, et. al.. Istanbul: Istanbul Büyükşehir Belediyesi, 1997.

Karpat, Kemal H. The Ottoman State and Its Place in World History. Leiden: Brill, 1974.

Kaya, Kemal. Tanzimat'tan Önce Belediye Hizmetleri ve Voyvodalar. Ankara: Dil ve Tarih-Coğrafya Fakültesi, Ankara Üniversitesi, 2007. 
Kaya, Mustafa İsmail. Shops and Shopkeepers in the Istanbul İhtisâb Register of 1092/1681 (Master Thesis in the Department of History, Bilkent University, Ankara, 2006.

Khadduri, Majid. "Islam and the Modern Law of Nations", The American Journal of International Law, Vol. 50 (1956).

Khalidi, Rashid. The Iron Cage: The Story of the Palestinian Struggle for Statehood. Great Britain: Oneworld Publications, 2007.

Khan, Ali. "The Reopening of the Islamic Code: The Second Era of Ijtihad", University of St. Thomas Law Journal, Vol. 1, (2003).

Lau, Martin. "The Independence of Judges Under Islamic Law, International Law and the New Afghan Constitution", ZaöRV, No. 64 (2004).

Lippman, Matthew. “Islamic Criminal Law and Procedure: Religious Fundamentalism v. Modern Law", Boston College International and Comparative Law Review, Vol. 12, Iss. 1 (1989).

Mazgarova, Sofia. "Islamic Reformism on the Periphery of the Muslim World: Rezaeddin Fakhreddin (1895-1936)", CGU Theses $\mathcal{E}$ Dissertations, Paper 8 (2010)

Munawwir, A.W. Kamus al-Munawwir Arab Indonesia. Surabaya: Pustaka Progressif, 1984.

Noulson, Noel J. A History of Islamic Law. Edinburgh: Edinburgh University Press, 1978.

Oguz, Orhan and Ahmed Tabakoglu. "An Historical Approach to Islamic Pricing Policy: A Research on the Ottoman Price System and its Application", JKAU: Islamic Econ., Vol. 3 (1411 A.H./1991 A.D.)

Ortayli, Ilber. "On the Role of the Ottoan Kadi in Provincial Administration", Turkish Public Administration Annual 3 (1076)

Ottoman Empire (Devlet-i 'Aliyye-i 'Osmâniyye), 3, available at https://www.alternatehistory.com > ... > Alternate History Discussion: Before 1900, accessed on July 15, 2017. 
Pamuk, Şevket. "Institutional Change and the Longevity of the Ottoman Empire, 1500-1800", Journal of Interdisciplinary History, Vol. XXXV, No. 2 (Autumn, 2004) . "The Evolution of Financial Institutions in the Ottoman Empire, 1600-1914", Financial History Review, Vol. 11, No. 1 (2004)

Peters, Rudholph. "From Jurists' Law to Statute Law or What Happens when the Shari'a is Codified", in Shaping the Current Islamic Reformation, ed. B.A. Roberson, London: Ebsco Publishing, 2003.

---orime and Punishment in Islamic Law: Theory and Practice from the Sixteenth to the Twenty-first Century. New York: Cambridge University Press, 2005.

Quataert, Donald. The Ottoman Empire, 1700-1922. Cambridge: Cambridge University Press, 2005.

Reza, Sadiq. "Due Process in Islamic Criminal Law", Geo. Wash. Int'l L., Vol. 46, Rev. 1 (2013-2014).

Şakul, Kahraman. “Selim III (b. 1761-d. 1808) (r. 1789-1807) Ottoman Sultan and Caliph, Reformer, and Composer" in Encyclopedia of the Ottoman Empire, eds. Gábor Ágoston \& Bruce Masters, New York: Facts on File, Inc., 2009.

Sari, Cahide Gulnur. "Hisbe Teskilatı", in Genc Hukukcular Hukuk Okumaları, Birikimler 3, ed. Muharrem Balcı. Istanbul: Hukuk Vakfı, 2009.

Savory, R.M. "The Principal Offices of the Șafawid State during the Reign of Ismā'ill I (907-30/1501-24)", Bulletin of the School of Oriental and African Studies, University of London, Vol. 23, No. 1 (1960)

Scahiner, A. The Sarrafs of Istanbul: Financiers of the Empire. MA Dissertation, Department of History, Bogh Aziçi University, 1995.

Schacht, J. An Introduction of Islamic Law, Oxford: Oxford University Press, 1959. 
Shaw, Stanford J. and Ezel Kural Shaw, History of the Ottoman Empire and Modern Turkey, Vol. II, Reform, Revolution, and Republic, The Rise of Modern Turkey 1808-1975. Cambridge: Cambridge University Press, 2004.

Shaw, Stanford S. History of the Ottoman Empire and Modern Turkey, Vol. I. Cambridge: Cambridge University Press, 2004.

Şimşek, Ayşe. Tarihte Gida Denetimi: Osmanli Bursa Ihtisab Kânunnamesi Örneği, A Paper Presented At International 3nd Halal And Healthy Food Congress, Istanbul, Turkey, October 30-31, 2015, available at www.helalvesaglikli.org/tr/icerik-goster/39, accessed on July 16, 2017.

Şimşek, Veysel. Ottoman Military Recruitment and the Recruit: 18261853. Master's Thesis at the Department of History, Bilkent University, Ankara, 2005.

Stone, Norman. "Turkey in the Russian Mirror", in Russia War, Peace and Diplomacy, eds. Mark \& Ljubica Erickson, London: Weidenfeld \& Nicolson, 2004.

Sunan Abû Dawûd, Book 14 Kitâb al-Jihâd, Number 3585, available at www.usc.edu/dept/MSA/fundamentals/hadithSunnahh/abu dawud, accessed on May 22, 2017.

Tulay, Arfan. The Anatolian Seljuks and The Ottoman Empire, https://research.sabanciuniv.edu/.../Artan,_Tülay__The_Anatolian_Seljuks_and_the_O..., accessed on July 15, 2017.

Turkish Cultural Foundation (TCF), A Brief Outline of Turkish History, 98, available at www.turkishculture.org/general-1067.htm, accessed on July 11, 2017.

Turkish Navy Official, Atlantik'te Türk Denizciliği, available at http:/ / www. dzkk. tsk. mil. tr/ TURKCE/ TarihiMiras/AtlantikteTurkDenizciligi. Asp, accessed on July 21, 2017.

Verhulst, A. The Rise of Cities in North-West Europe. Cambridge: Cambridge University Press, 1999. 
Welchman, Lynn. Women and Muslim Family Laws in Arab States: A Comparative Overview of Textual Development and Advocacy. Amsterdam: Amsterdam University Press, 2007.

Wikipedia, the Free Encyclopedia, "Agoranomos", available at https://en.wikipedia.org/wiki/Agoranomos, accessed on July 12, 2017.

Winter, Michael. The Judiciary of Late Mamluk and Early Ottoman Damascus: The administrative, Social and Cultural Transformation of the System. Bonn: ASK Working Paper 05, 2012.

Yatim, Badri. Sejarah Peradaban Islam (Dirasah Islamiyah II). Bandung: PT. Raja Grafindo Persada, 2000.

Yavuz, M. Hakan and John L. Esposito, Turkish Islam and the Secular State. New York: Syracuse University Press, 2003.

Yi, Eunjeong. Guild Dynamics in Seventeenth-Century Istanbul: Fluidity and Leverage. Leiden: E.J. Brill, 2004.

Yıldirım, Onur. "Craft Guilds in the Ottoman Empire (c. 1650-1826): A Survey “, METU Studies in Development, Vol. 27, No. 3-4 (2000),

---------. "Ottoman Guilds as a Setting for Ethno-Religious

Conflict: The Case of the Silk-thread Spinners' Guild in Istanbul", IRSH, 47 (2002) 